\title{
PAYING THE HIGH PRICE OF ACTIVE MANAGEMENT: A NEW LOOK AT UNIT TRUST FEES
}

\author{
C. Janse van Rensburg and J.D. Krige*
}

\begin{abstract}
T his study attempts to allocate the fund management expenses of actively managed South African general equity unit trusts between active and passive management portions, thereby calculating the implicit cost of active management. The active expense ratio of a unit trust can be calculated by using the published total expense ratio (TER) of the unit trust, its correlation relative to its benchmark and the expense ratio of a comparable exchange traded fund (ETF) tracking the benchmark of the unit trust.

This study focuses on actively managed South African equity unit trusts available to the retail investor for the period March 2007 to February 2015. The active expense ratios of these unit trusts were calculated on the basis of a three-, five- and eight-year analysis period.

It was found that the mean active expense ratios of the South African unit trust sample amounted to $4,14 \%, 4,29 \%$ and $4,25 \%$ respectively in the case of the three-, five- and eight-year periods. The comparable mean reported TERs amounted to $1,60 \%, 1,61 \%$ and $1,61 \%$ respectively. Thus the mean active expense ratio is more than $150 \%$ higher than the comparable mean reported TER in each period.

A similar study was conducted by Miller (2010), investigating the active expense ratios of actively managed large cap American unit trusts. He found that the mean active expense ratio was $6.44 \%$, compared with a mean TER of $1.20 \%$. However, due to a higher degree of active management being employed by South African managers, the active expense ratios are lower than those of the American counterparts.
\end{abstract}

\footnotetext{
* Stellenbosch University, Private Bag X1, Matieland, 7602, South Africa Email: jdkrige@sun.ac.za
} 


\section{Introduction}

The debate whether actively managed funds provide superior returns net of fees when compared to Exchange Traded Funds (ETFs) is an ongoing global debate. Miller (2010) showed that numerous actively managed American unit trusts are in fact "closet" index funds, but charge fees much higher than that of an ETF that tracks the same index. Similarly, Cremers and Petajisto (2009) observed that an increase in ETF investment has led to a decrease in active share.

This trend is also evident in South Africa. Muller and Ward (2011) conducted a study based on a sample of 90 actively managed South African general equity unit trusts, analysing their performance between 1998 and 2010. They found that the level of active share declined from 55\% in 1998 to $15 \%$ in 2001 . The level of active share has remained at this level from 2001 to 2010.

This trend begs the question: are high fees still justifiable in the case of actively managed unit trusts? Furthermore: what is the true cost of active management? The purpose of this study is an attempt to answer the second question by applying the approach developed by Miller (2007) to South African unit trusts for the period March 2007 to February 2015.

Miller (2007) developed a method to decompose a unit trust portfolio into a purely passive component, the portion of the portfolio that is equivalent to investing in one or more index-tracking funds, and an active component, the portion that is uncorrelated with the benchmark. This decomposition enables the true cost of active management to be calculated and is termed the active expense ratio. Furthermore, through isolating the active component of the unit trust, performance measures such as alpha can be adjusted to determine the effect of active management on performance (termed the active alpha).

The method described by Miller (2007) enables the active expense ratio and active alpha to be calculated without any knowledge of the underlying assets held in the unit trust portfolio. The approach uses the $\mathrm{R}^{2}$ of the unit trust (performance variance that can be explained by the benchmark) to determine the active expense ratio and active alpha of the fund. Miller (2007) argued that the active expense ratio, as a gauge of fund costs, is a better measurement than the traditional total expense ratio (TER), because the explicit cost of indexed alternatives is recognised.

The structure of the study is as follows: Section 2 provides a review of the relevant literature; Section 3 describes the data used and methodology employed in performing the analysis; Section 4 provides a discussion of the empirical findings and Section 5 concludes. 


\section{Literature review}

Jensen (1968) found that, on average, investing in an actively managed fund was not worthwhile to an investor. The measure of fund performance (alpha, or Jensen's alpha) was found on average to be negative when unit trust returns were adjusted for the amount of market risk (beta) inherent in the funds. Furthermore, he found that the expense ratio of funds correlated with the magnitude of negative performance.

Brinson, Hood and Beebower (1986) analysed the performance of 91 US pension funds for the period 1974 to 1983 and found that, on average, 93,6\% of the pension fund return variances could be attributed to passive portfolio management. This led Kirzner (2000) to conclude that asset allocation has a much larger impact on portfolio returns than market timing and security selection.

Bhattacharya and Galpin (2005) examined actively managed funds in 43 countries (including South Africa) and found that the level of active positions had declined throughout the world. They found that the level of active management is higher in the developing markets (average of 63\%) compared with the developed world (average of $45 \%$ ).

Huij (2007) found that systematic risk factors could account for $82 \%$ of return variances in US funds over a period of 40 years up to 2003. The high percentage of returns being attributed to indices shows that there is very little room for active management to add value to the portfolios beyond that of market indices.

In a study of the performance of 2650 American unit trusts from 1980 to 2003, Cremers and Petajisto (2009) found that the funds with the highest level of active management outperformed the benchmarks by $1,5 \%$ per annum. However, they also found that the level of active management declined over the study period. Almost all funds had, on average, a 60\% level of active management in the 1980s, but this declined to half of funds having a level of active management of less than $60 \%$ by 2003.

Muller and Ward (2011) conducted a study with a sample of 90 South African general equity funds, measuring the performance of these funds between 1998 and 2010. They found no evidence of successful active positions being taken in the equity market which may justify higher fees charged by fund managers. They also found that the level of active share in South Africa declined from a level of 55\% in 1998 to a level of $15 \%$ in 2001. The level of active share has remained at this level from 2001 to 2010. Furthermore, Muller and Ward (2011), in contrast to Cremers and Petajisto (2009), found no relationship between the level of active share and the risk-adjusted performance of funds. 
The finding of Cremers and Petajisto (2009) that an increase in ETF investment has led to a decrease in active share has led to the observation that many unit trusts are now seen as closet index funds. Closet index funds, or shadow index funds, were described by Bogle (1999) as those actively managed unit trusts with a coefficient of determination in excess of $95 \%$ when compared with the return obtained from the benchmark index.

Miller (2007), using data from 2002 to 2004 to compute the active expense ratios of 116 large cap American unit trust funds which tracked the S\&P500 Index, found the average active expense ratio of these funds to be $7,57 \%$. Furthermore, for a broader sample of 4754 American unit trust funds, which included both institutional and retail funds, the average active expense ratio was calculated to be 5,20\%. In his study, Miller (2007) found the average $\mathrm{R}^{2}$ value of the 116 large cap unit trusts to be $95,91 \%$. For the complete sample of 4754 mutual funds, it was found that the average $\mathrm{R}^{2}$ value was $90,24 \%$. In both samples Miller (2007) found that the overall fund performance was negative when compared to the benchmark indices $(-1,55 \%$ in the former sample and $-0,59 \%$ in the latter sample).

Miller (2010), using data covering the three-year period from 2007 to 2009, showed that the active expense ratio of 731 actively managed large cap American unit trusts ranged between $1,07 \%$ and $19,25 \%$, with a mean of $6,44 \%$ and a median of $6,15 \%$. Miller (2010) furthermore showed that the 731 American unit trust funds had an $\mathrm{R}^{2}$ of $95,08 \%$ and that the overall average performance, as measured by Jensen's alpha, was $-0,51 \%$ per annum. The reality, as argued by Miller (2010), is that many actively managed unit trusts have returns that are closely correlated with comparable ETFs, but the fees charged are significantly more.

\section{Data and research methodology}

Unit trusts were included in these study if they met the following criteria:

- Unit trusts with data available for at least 36 months. Therefore, unit trusts launched after March 2012 were excluded from the study;

- Unit trusts with at least $80 \%$ of its assets invested in equities;

- Only unit trusts sold to idividual investors (Class A unit trusts) were considered;

- All Fund of Funds unit trusts were excluded.

The Association for Savings and Investment South Africa (ASISIA, 2015) published data for 841 unit trusts classified as South African unit trusts on 31 December 2014. After applying the criteria listed above, the three-year unit trust sample included 87 unit trusts, the five-year unit trust sample included 72 unit trusts, while the eight-year unit trust sample included 52 unit trusts. The unit trusts that met the minimum criteria 
were classified as either Financial funds, General funds, Industrial funds, Large Cap funds, Mid and Small Cap funds or Resources and Basic Industries funds.

The published fact sheet of each unit trust was sourced from the website of the managing company. The unit trust fact sheets were scrutinised to obtain the benchmark, TER and inception date of each unit trust. In order to perform a unit trust performance analysis, the individual unit trust Net Asset Value (NAV) prices were sourced from the iNet BFA electronic database. The NAV price calculated at the close of business on the last working day of each month was used for unit trust performance calculations.

The month-end NAV prices for each benchmark, corresponding to the date of the unit trust NAV price data, were also sourced from the iNet BFA electronic database. In the case where a benchmark was not a JSE Index (an example being a benchmark based on the average of the returns of a specific ASISA category of unit trusts), the fund was regressed against the different benchmarks used by the category peers. The JSE Index which produced the highest $\mathrm{R}^{2}$ value was then used as the benchmark for this particular unit trust.

Previous studies on South African unit trusts (Oldfield \& Page, 1997; Meyer, 1998; Von Wielligh \& Smit, 2000; Scher \& Muller, 2005) used the 91-day Treasury Bill rate as a proxy for the South African risk-free rate. In keeping with these studies, the daily 91-day Treasury Bill discount rate was sourced from the South African Reserve Bank website.

Monthly unit trust performance was calculated based on raw percentage returns between the start and end of the month being reviewed. The increase in NAV per unit in the unit trust was calculated as follows:

$$
R_{i, t}=\frac{P_{i, t}-P_{i, t-1}+D_{i, t}}{P_{i, t-1}}
$$

where $R_{i, t}=$ the holding period rate of return of unit $i$ at time $t$ expressed in percent

$\mathrm{P}_{\mathrm{i}, \mathrm{t}}=$ closing price per unit at time $\mathrm{t}$

$\mathrm{P}_{\mathrm{i}, \mathrm{t}-\mathrm{l}}=$ closing price per unit at time $\mathrm{t}-1$

$\mathrm{D}_{\mathrm{i}, \mathrm{t}}=$ any income to the unit trust investor during the holding period

Miller (2010) argued that unit trusts bundle alpha and beta, which, simply stated, means that an actively managed unit trust is a combination of a pure hedge fund (the alpha component) and an index tracking fund (the beta component). The relative size of the alpha and beta components can be estimated by regressing the historical returns of the fund with the historical returns of the benchmark, after subtracting the risk- 
free rate from both returns. The results of the regression analysis are indicative of what proportion of a the performance of a unit trust can be attributed to passive investment choices and what proportion is due to the active choices of the manager of the unit trust.

Through the regression analysis, the coefficient of determination $\left(\mathrm{R}^{2}\right)$ represents the component of the total returns of the fund which is as a result of index returns (Miller, 2010). The value given by $1-\mathrm{R}^{2}$ therefore is indicative of the returns of the fund as a result of the actively managed component.

The monthly performance data of each unit trust, after allowing for the risk-free rate, was used to perform a regression analysis against the performance of the benchmark of the unit trust (net of the risk-free rate). The results yielded the coefficient of determination $\left(\mathrm{R}^{2}\right)$ and $\mathrm{y}$-intercept, which is indicative of the performance of the unit trust ( $\left.\alpha_{\text {fund }}\right)$ compared to the benchmark.

In order to separate the active and passive components of unit trusts, Miller (2007) explains that the TER of the unit trust can be calculated by the weighted sum of the two components:

$$
\mathrm{C}_{\mathrm{P}}=\left(1-\mathrm{w}_{\mathrm{A}}\right) \mathrm{C}_{\mathrm{I}}+\mathrm{w}_{\mathrm{A}} \mathrm{C}_{\mathrm{A}}
$$

where $\quad C_{p}=$ the TER of the unit trust

$\mathrm{C}_{\mathrm{I}}=$ the TER of investing in a comparable ETF

$\mathrm{C}_{\mathrm{A}}=$ active expense ratio

$\mathrm{w}_{\mathrm{A}}=$ proportion of the unit trust being actively managed

Miller (2010) explains that variances between the returns of the fund and the returns of the benchmark do not vary linearly, but rather correspond to the square of the returns. Therefore, the ratio of the passively managed component to the actively managed component can be calculated from the following equation:

$$
\frac{\text { Passive component }}{\text { Active component }}=\sqrt{\frac{\mathrm{R}^{2}}{\left(1-\mathrm{R}^{2}\right)}}
$$

Miller (2010) described that the ratio of the passively managed component to the actively managed component calculated in Equation 3 above, indicates that an investor can statistically replicate the returns from the actively managed fund by investing the calculated ratio in the index fund for every one Rand invested in the actively managed component. 
The actively managed proportion can furthermore be expressed as follows (Miller, 2007):

$$
w_{\mathrm{A}}=\frac{\sqrt{1-R^{2}}}{\mathrm{R}+\sqrt{1-R^{2}}}
$$

Using Equations 2 and 4, the active expense ratio of a unit trust, $\mathrm{C}_{\mathrm{A}}$, can be calculated (Miller, 2007):

$$
C_{A}=C_{P}+\frac{R\left(C_{P}-C_{I}\right)}{\sqrt{\left(1-R^{2}\right)}}
$$

Equation 5 allows the active expense ratio to be calculated by only having access to the values for the coefficient of determination $\left(\mathrm{R}^{2}\right)$, the TER of the unit trust being evaluated and the TER of the comparable ETF. This equation illustrates that the active expense ratio $\left(\mathrm{C}_{\mathrm{A}}\right)$ increases with both an increase in $\mathrm{R}^{2}$ relative to the benchmark and an increase in the TER of the unit trust, $\mathrm{C}_{\mathrm{p}}$. When the cost of investing in an $\operatorname{ETF}\left(\mathrm{C}_{\mathrm{I}}\right)$ increases, the active expense ratio will decrease.

Similar to Equation 2, the alpha of a unit trust can be expressed as follows (Miller, 2007):

$$
\alpha_{\mathrm{P}}=\mathrm{w}_{\mathrm{A}} \alpha_{\mathrm{A}}+\left(1-\mathrm{w}_{\mathrm{A}}\right) \alpha_{\mathrm{I}}
$$

where $\quad \alpha_{\mathrm{P}}=$ unit trust fund's performance relative to the benchmark,

$\alpha_{A}=$ the fund's performance that can be attributed to the active component in a unit trust

$\mathrm{w}_{\mathrm{A}}=$ proportion of the unit trust being actively managed and $\alpha_{\mathrm{I}}=$ comparable ETF's performance.

Miller (2007) followed a conservative approach by assuming that the cost of investing in an ETF, $\mathrm{C}_{\mathrm{I}}$, would have the net effect of eroding the ETF's return so that the ETF's alpha will be equal to the negative of the ETF's expense ratio, $C_{I}$. Equation 6 can therefore be written as follows:

$$
\alpha_{\mathrm{P}}=\mathrm{w}_{\mathrm{A}} \alpha_{\mathrm{A}}-\left(1-\mathrm{w}_{\mathrm{A}}\right) C_{\mathrm{I}}
$$

The formula to calculate the active alpha, $\alpha_{\mathrm{A}}$, as described by Miller (2007) can therefore be written as follows:

$$
\alpha_{\mathrm{A}}=\alpha_{\mathrm{P}}+\frac{\mathrm{R}\left(\alpha_{\mathrm{P}}+\mathrm{C}_{\mathrm{I}}\right)}{\sqrt{\left(1-\mathrm{R}^{2}\right)}}
$$


Similar to the active expense ratio calculation, the active alpha can be calculated by only having access to the values for the coefficient of determination $\left(\mathrm{R}^{2}\right)$, the alpha of the unit trust being evaluated and the TER of the comparable ETF.

\section{Results}

Tables 1, 2 and 3 contain summaries of the results obtained for the unit trust funds included in the three-, five- and eight-year sample analysis.

Table 1: Summary of the actively managed unit trust funds contained in the three-year sample

\begin{tabular}{l|c|c|c|c|c|c|c}
\hline \multirow{2}{*}{ Category } & & \multicolumn{7}{|c}{ Sample mean } \\
\cline { 2 - 8 } & $\begin{array}{c}\text { Funds } \\
\text { in } \\
\text { sample }\end{array}$ & $\begin{array}{c}\mathbf{R}^{\mathbf{2}} \\
(\mathbf{\%})\end{array}$ & $\begin{array}{c}\text { Total } \\
\text { managed } \\
\text { portion } \\
(\mathbf{\%})\end{array}$ & $\begin{array}{c}\text { Active } \\
\text { Expense } \\
\text { Ratio, } \\
\mathbf{C}_{\mathbf{p}} \\
(\mathbf{\%})\end{array}$ & $\begin{array}{c}\text { Expense } \\
\text { ratio, } \\
\mathbf{C}_{\mathbf{A}} \\
(\mathbf{\%})\end{array}$ & $\begin{array}{c}\text { Fund } \\
\text { Alpha, } \\
\boldsymbol{\alpha}_{\mathbf{P}} \\
(\mathbf{\%})\end{array}$ & $\begin{array}{c}\text { Active } \\
\text { Alpha, } \\
\boldsymbol{\alpha}_{\mathbf{A}} \\
(\mathbf{\%})\end{array}$ \\
\hline Financials & 6 & 84,16 & 30,09 & 1,60 & 4,26 & $-0,12$ & 0,68 \\
\hline General & 63 & 74,54 & 35.98 & 1,60 & 4,15 & $-0,02$ & 0,49 \\
\hline Industrial & 5 & 74,34 & 36,55 & 1,54 & 3,48 & 0,23 & 1,48 \\
\hline $\begin{array}{l}\text { Mid- and Small- } \\
\text { Cap }\end{array}$ & 6 & 47,05 & 51,63 & 1,55 & 2,44 & 0,04 & 0,77 \\
\hline $\begin{array}{l}\text { Resources and } \\
\text { Basic Industries }\end{array}$ & 7 & 91,23 & 23,32 & 1,67 & 5,86 & 0,08 & 1,92 \\
\hline Total & $\mathbf{8 7}$ & $\mathbf{7 4 , 6 4}$ & $\mathbf{3 5 , 6 7}$ & $\mathbf{1 , 6 0}$ & $\mathbf{4 , 1 4}$ & $\mathbf{0 , 0 0}$ & $\mathbf{0 , 6 9}$ \\
\hline
\end{tabular}

The results of the three-year analysis show that most of the South African unit trust funds have actively managed portions in excess of $30 \%$, or relatively low coefficients of determination when compared to the respective benchmarks. The exception is the Resources and Basic Industries category, where the $\mathrm{R}^{2}$ value is in excess of $90 \%$, which results in a lower actively managed portion being present in these funds. The Mid and Small Cap category contains the unit trust funds with the highest actively managed portion compared with the rest of the funds classified as Equity funds.

The different unit trust categories have similar mean TERs, but the active expense ratios differ significantly. The categories with high $\mathrm{R}^{2}$ values (Resources and Basic Industries) provide less active management at a higher active expense ratio than the categories with low $\mathrm{R}^{2}$ values (Industrial and Mid and Small Cap).

The results summarised in Table 1 show that active management contributed positively to the average performance of the funds contained in the three-year samples. This can be seen from the positive mean active alphas. However, active management in the Financial and General categories did not contribute enough, on 
average, for the funds to obtain overall positive performance when compared to the benchmarks, as can be seen in the negative overall fund alphas.

The results summarised in Tables 1 through 3 indicate that the actively managed portion increased over the last eight years. This is due to the fact that the sample average $\mathrm{R}^{2}$ values decreased from $81,36 \%$ over the past eight years to $79,19 \%$ over the last five years and $74,64 \%$ over the last three years.

However, it should be noted that the increase in active management did not, on average, result in improved unit trust fund performance. This is seen from the overall fund alphas being close to $0 \%$ for all the analysis periods. It can be concluded that the unit trust fund managers were hardly able to earn back their fees as reflected in the mean fund alphas.

Table 2: Summary of the actively managed unit trust funds contained in the five-year sample

\begin{tabular}{|c|c|c|c|c|c|c|c|}
\hline \multirow[b]{2}{*}{ Category } & \multirow[b]{2}{*}{$\begin{array}{l}\text { Funds } \\
\text { in } \\
\text { sample }\end{array}$} & \multicolumn{6}{|c|}{ Sample mean } \\
\hline & & $\begin{array}{l}\mathbf{R}^{2} \\
(\%)\end{array}$ & $\begin{array}{c}\text { Actively } \\
\text { managed } \\
\text { portion } \\
(\%)\end{array}$ & $\begin{array}{c}\text { Total } \\
\text { Expense } \\
\text { Ratio, } \\
\text { C }_{p} \\
(\%)\end{array}$ & $\begin{array}{c}\text { Active } \\
\text { Expense } \\
\text { ratio, } \\
\mathrm{C}_{\mathrm{A}} \\
(\%)\end{array}$ & $\begin{array}{c}\text { Fund } \\
\text { Alpha, } \\
\underset{\alpha P}{(\%)} \\
(\%)\end{array}$ & $\begin{array}{c}\text { Active } \\
\text { Alpha, } \\
\boldsymbol{\alpha}_{\mathbf{A}} \\
(\%)\end{array}$ \\
\hline Financials & 6 & 86.31 & 28.33 & 1.60 & 4.50 & 0.02 & 1.23 \\
\hline General & 48 & 78.58 & 33.50 & 1.61 & 4.30 & 0.05 & 0.85 \\
\hline Industrial & 5 & 81.22 & 32.24 & 1.54 & 3.86 & 0.20 & 1.61 \\
\hline $\begin{array}{l}\text { Mid and Small } \\
\text { Cap }\end{array}$ & 6 & 61.69 & 43.87 & 1.55 & 2.74 & 0.16 & 1.26 \\
\hline $\begin{array}{l}\text { Resources and } \\
\text { Basic Industries }\end{array}$ & 7 & 90.85 & 23.76 & 1.67 & 5.73 & 0.13 & 2.11 \\
\hline Total & 72 & 79.19 & 32.90 & 1.61 & 4.29 & 0.07 & 1.09 \\
\hline
\end{tabular}


Table 3: Summary of the actively managed unit trust funds contained in the eight-year sample

\begin{tabular}{|c|c|c|c|c|c|c|c|}
\hline \multirow[b]{2}{*}{ Category } & \multirow[b]{2}{*}{$\begin{array}{l}\text { Funds } \\
\text { in } \\
\text { sample }\end{array}$} & \multicolumn{6}{|c|}{ Sample mean } \\
\hline & & $\begin{array}{l}\mathbf{R}^{2} \\
(\%)\end{array}$ & $\begin{array}{c}\text { Actively } \\
\text { managed } \\
\text { portion } \\
(\%)\end{array}$ & $\begin{array}{c}\text { Total } \\
\text { Expense } \\
\text { Ratio, } \\
\text { C }_{p} \\
(\%)\end{array}$ & $\begin{array}{c}\text { Active } \\
\text { Expense } \\
\text { ratio, } \\
\text { CA }_{A} \\
(\%)\end{array}$ & $\begin{array}{c}\text { Fund } \\
\text { Alpha, } \\
\alpha_{\mathbf{P}} \\
(\%)\end{array}$ & $\begin{array}{c}\text { Active } \\
\text { Alpha, } \\
\boldsymbol{\alpha}_{\mathrm{A}} \\
(\%)\end{array}$ \\
\hline Financials & 5 & 89.05 & 25.82 & 1.63 & 5.02 & 0.19 & 2.07 \\
\hline General & 32 & 80.40 & 32.47 & 1.61 & 4.13 & -0.09 & 0.61 \\
\hline Industrial & 5 & 83.02 & 30.94 & 1.54 & 4.02 & -0.03 & 0.89 \\
\hline $\begin{array}{l}\text { Mid and Small } \\
\text { Cap }\end{array}$ & 4 & 68.31 & 40.22 & 1.60 & 3.07 & -0.05 & 0.86 \\
\hline $\begin{array}{l}\text { Resources and } \\
\text { Basic Industries }\end{array}$ & 6 & 87.37 & 27.12 & 1.71 & 5.25 & 0.12 & 1.75 \\
\hline Total & 52 & 81.36 & 31.66 & 1.61 & 4.25 & -0.03 & 0.93 \\
\hline
\end{tabular}

Figure 1 illustrates a box and whisker diagram showing the distribution of the active expense ratios for the 87 unit trust funds contained in the three-year analysis period. For comparative purposes, the individual fund TERs are also included. Similarly, Figures 2 and 3 illustrate the same active expense ratio and TER distributions for the 72 funds contained in the five-year analysis and the 52 funds contained in the eightyear analysis.

The funds included in the three-year analysis have TERs that range between $0,60 \%$ and $2,75 \%$, with a mean of $1,60 \%$ and a median of $1,65 \%$. The active expense ratios range between $1,53 \%$ and $8,71 \%$, with a mean of $4,14 \%$ and median of $3,99 \%$. The active expense ratios of the five-year analysis period range between $1,62 \%$ and $7,39 \%$. The mean active expense ratio is $4,29 \%$ and the median is $3,96 \%$. The eightyear active expense ratios range between $1,01 \%$ and $7,22 \%$, with a mean of $4,25 \%$ and median of $4,28 \%$.

The active expense ratio results obtained for the South African actively managed unit trusts are lower than those obtained in the American studies by Miller $(2007 ; 2010)$. Miller (2010) showed in a study of 731 actively managed retail large cap American unit trusts, using data covering the three-year period from 2007 to 2009, that the active expense ratios of these unit trusts ranged between $1,07 \%$ and $19,25 \%$, with a mean of $6,44 \%$ and median of $6,15 \%$. The mean active expense ratio of $6,44 \%$ is extremely high when one considers that the mean TER published by the unit trusts was $1,20 \%$. 
The South African actively managed unit trusts have higher published TERs (sample average of $1,61 \%$ ), but due to a higher degree of active management being employed the active expense ratios are lower than those of the American counterparts.

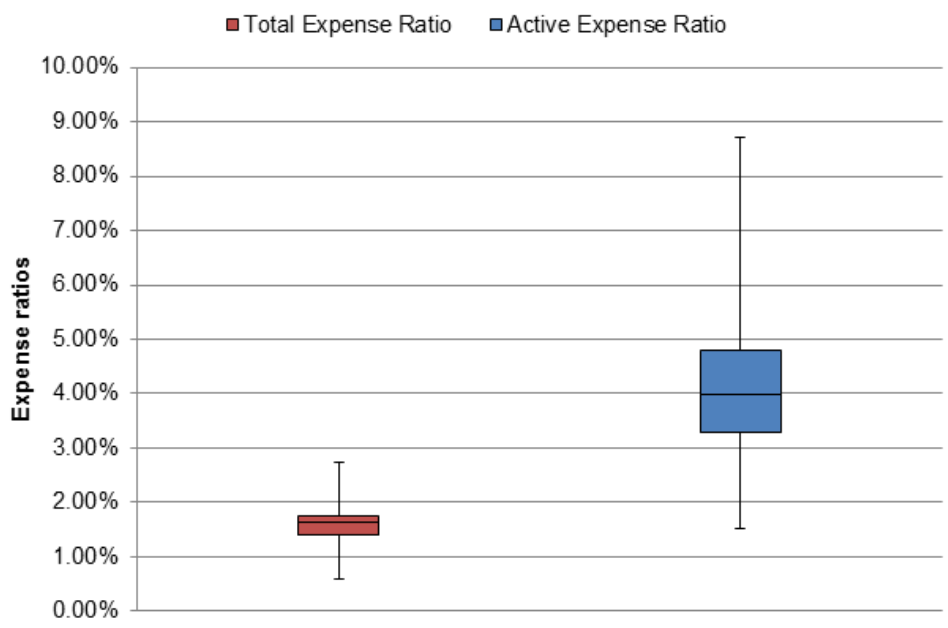

Figure 1: Distribution of TERs and active expense ratios of the 87 unit trust funds contained in the three-year sample

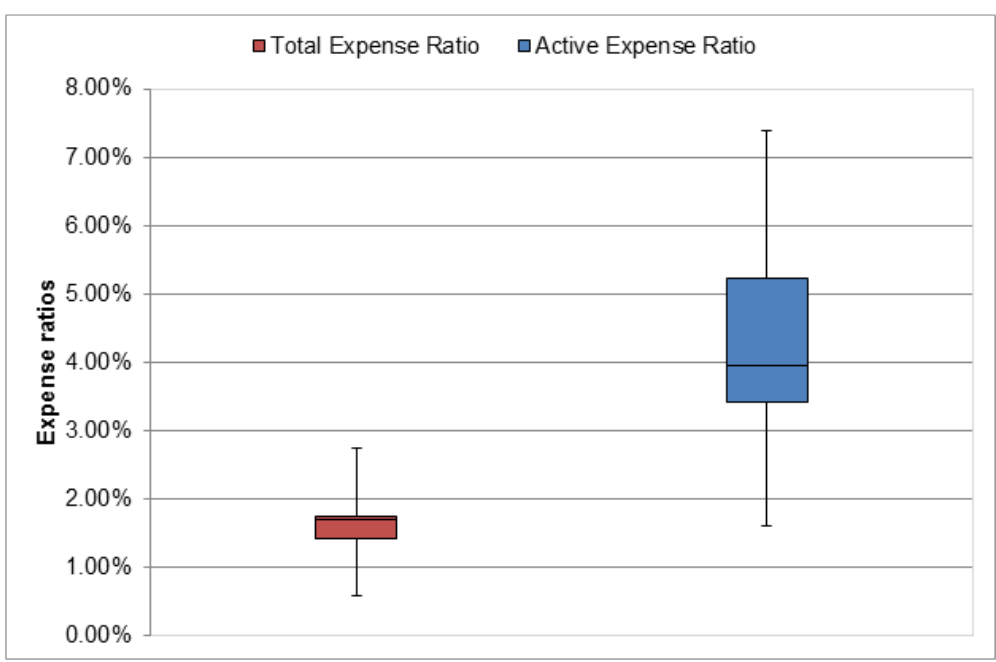

Figure 2: Distribution of TERs and active expense ratios of the 72 unit trust funds contained in the five-year sample 


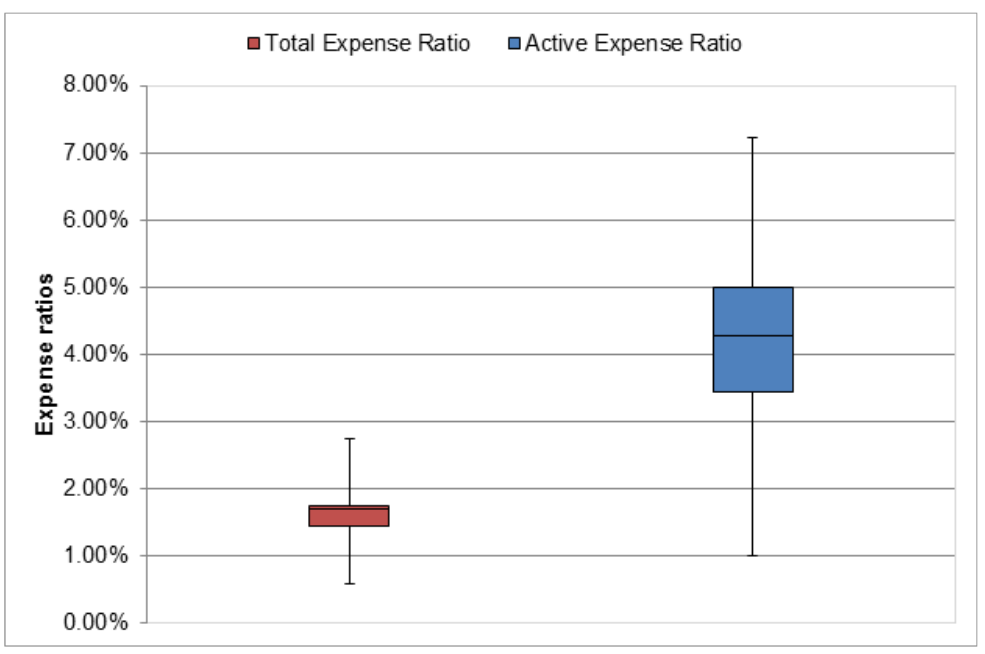

Figure 3: Distribution of TERs and active expense ratios of the 52 unit trust funds contained in the eight-year sample

Figure 4 illustrates a box and whisker diagram showing the distribution of the active alphas for the 87 unit trust funds contained in the three-year analysis. The overall fund alphas are also included for comparative purposes. Similarly, Figures 5 and 6 illustrate the same active alpha and overall fund alpha distributions for the 72 funds contained in the five-year analysis and 52 funds contained in the eight-year analysis.

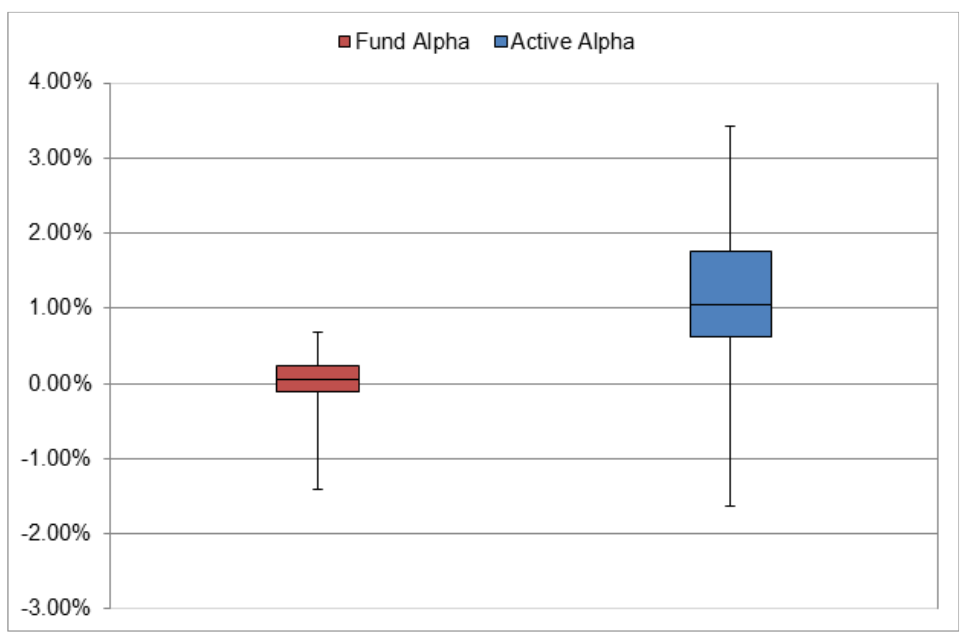

Figure 4: Distribution of active alphas for the 87 unit trust funds contained in the three-year sample 


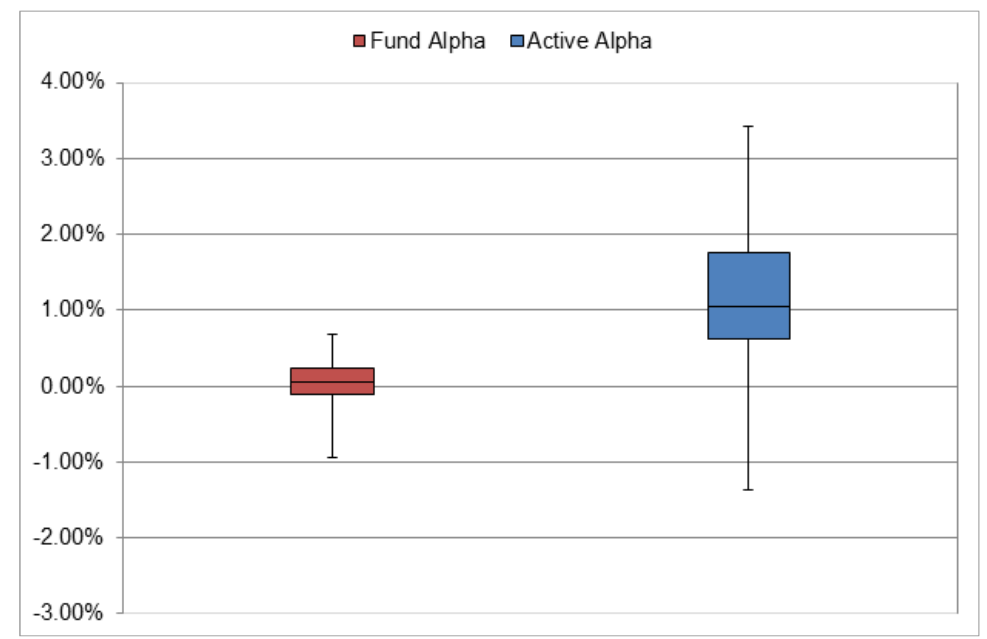

Figure 5: Distribution of active alphas for the $\mathbf{7 2}$ unit trust funds contained in the five-year sample

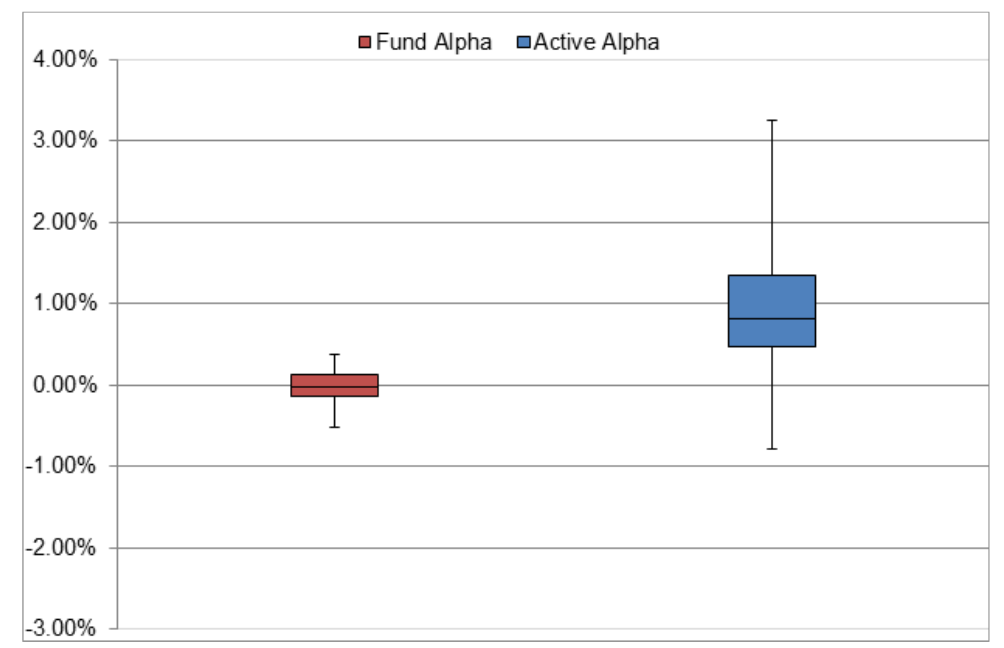

Figure 6: Distribution of active alphas for the 52 unit trust funds contained in the eight-year sample

The funds in the three-year analysis have active alphas that range between -2,11\% and $3,45 \%$, with a mean of $0,69 \%$ and a median of $0,76 \%$. The active alphas in the five-year analysis range between $-1,38 \%$ and $3,41 \%$. The mean active alpha is $1,09 \%$ and the median is $1,05 \%$. The eight-year active alphas range between $-0,79 \%$ and $3,25 \%$, while having a mean of $0,93 \%$ and median of $0,81 \%$. 
Although the amount of active management has increased over the eight years, it would appear that the quality of the active management has decreased. This is evident from the results observed in the three-year analysis; it can be seen that a number of funds had large negative active alphas, compared with only four funds having negative active alphas in the eight-year analysis.

In order to determine whether fund size had an effect on the degree of active management, the three-, five- and eight-year individual unit trust $\mathrm{R}^{2}$ values were compared with the fund sizes (expressed as total assets under management). Figure 7 graphically represents this comparison: It can be seen that the large funds have high $\mathrm{R}^{2}$ values, therefore low active management. Smaller funds provide a higher degree of active management (lower $\mathrm{R}^{2}$ values). This conclusion is valid for all analysis periods.

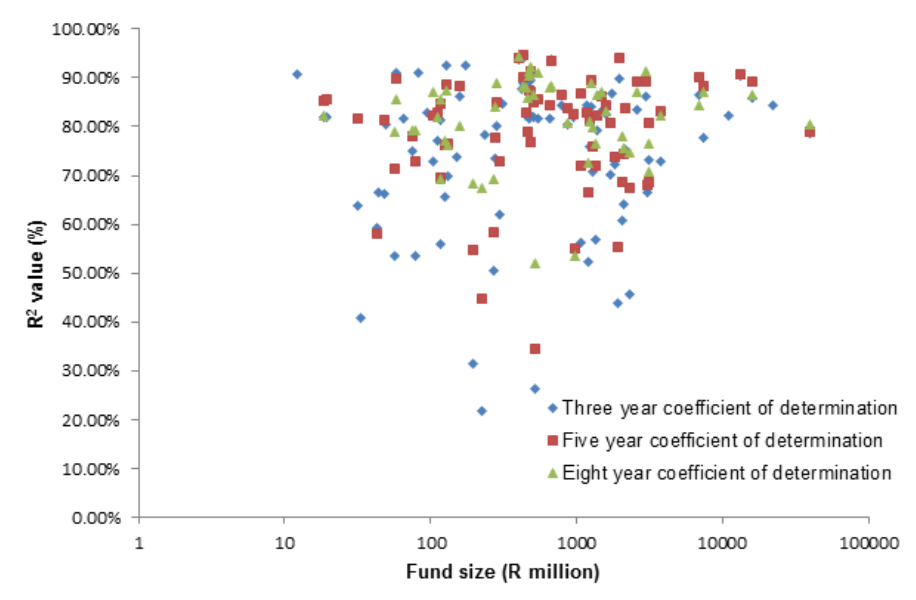

Figure 7: Comparison of unit trust fund $R^{2}$ values as a function of fund size

Figure 8 graphically illustrates how the active expense ratios of the unit trust funds differ with regards to fund size. The figure shows that most of the largest South African unit trust funds (having more than R6 billion of assets under management) have greater active expense ratios than mid-sized unit trust funds. However, there is no direct correlation between fund size and active expense ratios: the smaller funds (less than R100 million) generally have greater active expense ratios when compared with mid-sized unit trusts. 


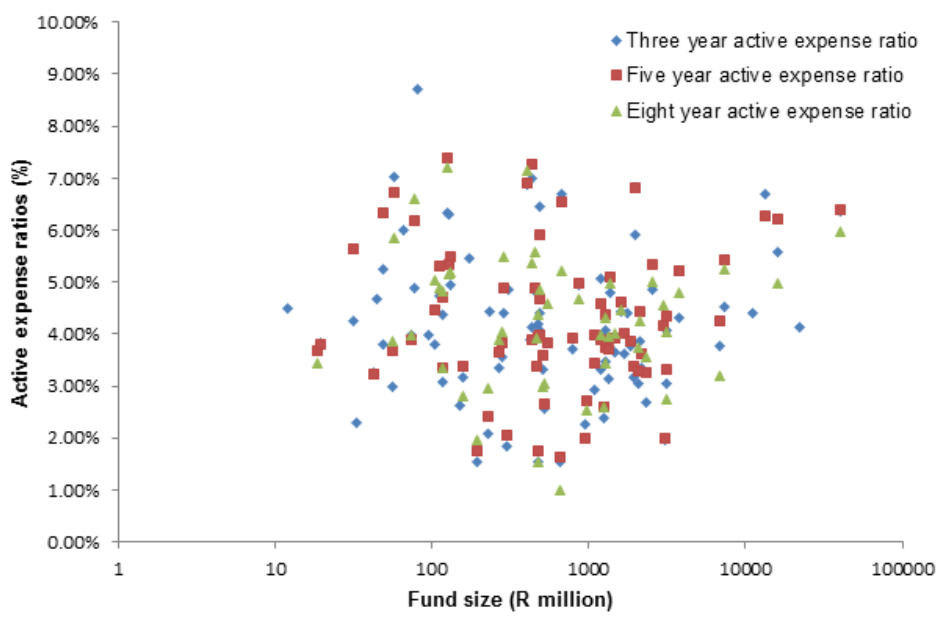

Figure 8: Comparison of unit trust fund active expense ratios as a function of fund size

Figure 9 graphically represents the three-, five- and eight-year active alphas as a function of unit trust fund size. The largest South African unit trust funds have positive active alphas when compared with the small unit trust funds (which tend to have negative active alphas). The mid-sized unit trust funds have a large spread of active alphas, as some funds provide active management that contributed more than $2 \%$ to the performance of the fund.

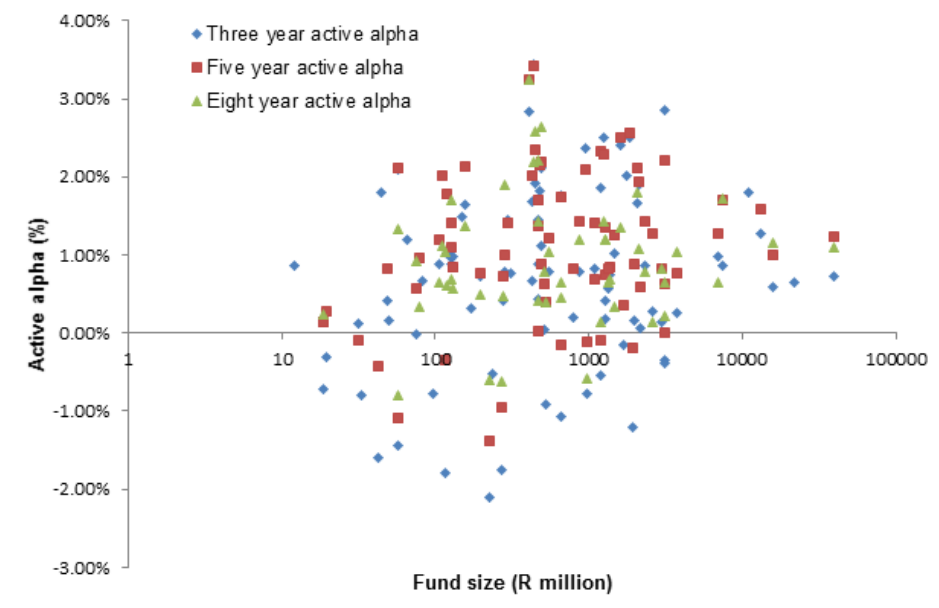

Figure 9: Comparison of unit trust fund active alphas as a function of fund size 


\section{Conclusion}

The method to calculate the true cost of portfolio management, as described by Miller (2007), is a practical method that allows the expenses of an actively managed unit trust to be divided into a passive and active portion, thus allowing the implicit cost of active management to be calculated.

The study showed that the mean TER of the sample of actively managed South African equity unit trusts was $1,60 \%, 1,61 \%$ and $1,61 \%$ respectively in the case of the three-, five- and eight-year periods of investigation. In contrast, the mean active expense ratios amounted to $4,14 \%, 4,29 \%$ and $4,25 \%$ respectively in the case of the three-, five- and eight-year periods of investigation.

These active expense ratios are lower than those obtained in comparable American studies (Miller, 2007; 2010), despite the fact that mean South African TERs are higher than those of the American funds studied. This is due to a higher degree of active management being employed in the case of the South African unit trusts.

This study shows that the mean active expense ratio is more than $150 \%$ higher than the comparable mean reported TER in each period of investigation. In addition, the mean South African TER of approximately 1,60\% compares unfavourably with the comparable American TER of 1,20\%. Finally, unit trust managers were hardly able to earn back their fees as reflected in the mean fund alphas in this study. These facts strengthen the case for investing in ETFs rather than actively managed South African equity unit trusts.

\section{References}

Association for Savings and Investment South Africa. 2015. Local Fund Statistics. [Online] Available: http://www.asisa.org.za/index.php/en/statistics/collective-investment-schemes/localfund-statistics Accessed: 2 March 2015.

Bhattacharya, U. \& Galpin, N. 2005. Is Stock Picking Declining Around the World? [Online] Available: http://public-stage-acquia.gsb.stanford.edu/sites/default/files/documents/Stock Picking.pdf Accessed 23 March 2015.

Bogle, J. 1999. Common Sense on Mutual Funds. New York: John Wiley \& Sons.

Brinson, G.P., Hood, L.R. \& Beebower, G.L. 1986. 'Determinants of portfolio performance', Financial Analysts Journal, 42(4): 39-44.

Cremers, K.J.M. \& Petajisto, A. 2009. 'How active is your fund manager? A new measure that predicts performance', The Review of Financial Studies, 22(9): 3329-3365. 
Fama, E.F. \& French, K.R. 2004. 'The capital asset pricing model: Theory and evidence', The Journal of Economic Perspectives, 18(3): 25-46.

Huij, J.J. 2007. New Insights into Unit trusts: Performance and Family Strategies. [Online] Available: http://papers.ssrn.com/sol3/papers.cfm?abstract_id=961819 Accessed 30 March 2015.

Jensen, M. 1968. 'The performance of mutual funds in the period 1945-1964', Journal of Finance, 23(2): 389-416.

Kirzner, E. 2000. Fact and Fantasy in Index Investing. [Online] Available: http://www.bylo.org/pdf/fact.fantasy.in.index.investing.pdf Accessed: 29 March 2015.

Meyer, M.C. 1998. 'The persistence of unit trust performance for the period July 1985 - June 1995', South African Journal of Business Management, 27(2): 9-21.

Miller, R.M. 2007. Measuring the true cost of active management by mutual funds. [Online] Available: http://home.earthlink.net/ millerrisk/Expenses/Miller_1Q2007_JOIM_True_Cost_of_ Active_Management.PDF Accessed 3 March 2015.

Miller, R.M. 2010. 'Paying the high price of active management: A new look at mutual fund fees', World Economics, 11(3): 5-23.

Muller, M. \& Ward, D. 2011. 'Active share on the JSE', Investment Analysts Journal, 74: 19-28.

Oldfield, C.E. \& Page, M.J. 1997. 'Assessing portfolio performance: The case of South African unit trusts', The Investment Analysts Journal, 44(2): 25-41.

Scher, N. \& Muller, C. 2005. 'Equity style and performance persistence in South African unit trusts', Investment Analysts Journal, 61: 5-16.

Von Wielligh, J.F. \& Smit, E.vdM. 2000. 'Persistence in the performance of South African unit trusts', South African Journal of Business Management, 31(3): 120-129.

Weiers, R.M. 2011. Introductory business statistics. $7^{\text {th }}$ Edition. South-Western, Cengage Learning. 
